\title{
Measuring the Quality of Provider Services with the Service Quality Method at the Public Health Center in Kotamobagu City Darmin $^{1 *}$, Sarman ${ }^{2}$
}

\author{
${ }^{1,2}$ Public health Studi Program, Faculty of Health Science, Health Institute and Technology \\ Graha Medika, Kotamobagu City, North Sulawesi, Indonesia \\ *Email: dharmyn@gmail.com
}

\begin{abstract}
One of the health service facilities that have a very important role in providing health services to the community is the Community Health Center. Assessment of the quality of health services is very important because it can be used as material for self-evaluation of health care provider organizations. assessment of research respondents using a questionnaire consisting of 30 statements. The purpose of this study was to evaluate the quality of public health services in all public health centers in Kotamobagu City. This research is a type of quantitative research, using an observational analytic approach with a questionnaire as a tool in collecting research data. The research was conducted at the Kotamobagu City off all Public Health Center in April 2021. The population in this study were all 1000 patients undergoing treatment at the Kotamobagu City Public Health Center, North Sulawesi province. samples in this study as many as 200 patients were determined using a Slovin calculation technique. The sampling technique in this study uses probability simple random sampling. The quality of health services at the Public Health Center in Kotamobagu City is not optimal, it is known that the health services felt by the community are not following what was conveyed by the health service manager at the Kotamobagu City Health Center with a significant level of $(\alpha=0.000<0.05)$. The quality of health services received by the community who utilize services in all Public Health Centers in Kotamobagu City is considered not optimal because the dimension that is lacking in its implementation in public health centers is the dimension of Reliability Responsiveness Assurance Empathy.
\end{abstract}

Keywords: Health Service Quality, Health Service Provider, Service Quality Method, Public Health Centers.

\section{Introduction}

Services in the health sector are one of the most needed forms of service by the community. One of the health service facilities that have a very important role in providing health services to the community is the Public Health Center (PUSKESMAS). Public Health Centers is a functional organization that organizes health efforts that are comprehensive, integrated, equitable, acceptable, and affordable by the community, with active community participation and using the results of the development of appropriate science and technology, with costs that can be borne by the government and the community, (Etlidawati \& Handayani, 2017).

Customer demands on various aspects of health services are increasing with the current industry so that the quality of health services provided by providers must of course be based on patient needs and end on patient perceptions or assessments. Therefore, good service quality is not only seen in terms of the perception or assessment of the service provider itself but based on 
the perception of the patient/customer/customer. The quality of health services in question is of course providing health services following the mandate of the law. In a service product such as health services, the patient's perception of service quality is a comprehensive assessment, (Fahmi, 2016).

Understanding the wishes of patients is a very important aspect to improve the quality of health services is important. Patients with a good assessment of health care providers become a very important asset in the sustainability of health services. To achieve this, a health care agency is required to determine a policy on resource asset management systems to maintain and improve service quality and patient satisfaction, (Herri, 2017).

Assessment of the quality of health services is very important because it can be used as material for self-evaluation of health service providers to find out how effective the health services provided to service users are. It is not enough to assess service quality only by using indicators attached to the bureaucracy/officers such as efficiency and effectiveness, but it is necessary to go through indicators attached to service users, such as service user needs, accountability, and responsiveness, (Sutriono \& Sudirman, 2020).

The importance of fulfilling the quality of patient care in public health centersin Kotamobagu City to increase service capacity and status in public health centers in Kotamobagu City. The quality of a health service can be met and assessed by examining 5 dimensions in health services, namely reliability, assurance, tangibles, empathy, and responsiveness., (Hadi, 2017). Based on the results of observations made on 24-27 May 2021 to 10 different informants, it was concluded that the public complained about the low attention of health workers to the patient's need for fast service, especially for patients who needed immediate service, and the response of health workers. which is still low on public complaints related to the need for health services, especially for patients who undergo intense treatment so that it can be seen that health workers pay less attention to patients in providing health services.

Updating technological facilities and programs in health services is one of the things that must be the center of attention in the field of health services, to create renewable health services by the time and public needs and disease development. Health facilities are one of the important aspects of health services at public health centers because they are a connector so that a health service policy can be conveyed to the public, (Sudirman, 2018). Considering that all health centers in Kotamobagu City are public health centers providers and act as spearheads in the development of public health both before the pandemic and during the current COVID-19 pandemic, it is necessary to measure the quality of health services to the community to improve the quality of health services. health services are provided in public health centers on an ongoing basis. The purpose of this study was to evaluate the quality of public health services in all public health centers in Kotamobagu City.

\section{Materials and Methods}

The assessment of respondents who received treatment in all Public Health Centers in Kotamobagu City used a questionnaire. The questionnaire that is used uses the RATER quality 
dimension assessment, consisting of 5 dimensions and consists of 30 statements. The question components have a weight value of 1 to 4 , where respondents who choose an answer that is worth 5 are classified as very good quality, and an answer that is worth 1 is classified as not good. RATER can be used as an assessment of the quality of health services. After obtaining consent from the patient to be a respondent in this study, the further assessment process in this study was carried out by conducting interviews with respondents using a questionnaire, to determine how good and how bad the health services received were.

This research is a type of quantitative research, using an observational analytic approach with a questionnaire as a tool in collecting research data. The research was conducted at the Kotamobagu City off all Public Health Centers (5 PUSKESMAS), in April 2021. The study was conducted at all public health centers in Kotamobagu city, North Sulawesi province. The population in this study were all 1000 patients undergoing treatment at the Kotamobagu City Public Health Center, North Sulawesi province. The sample in this study as many as 200 patients were determined using a Slovin calculation technique.The sampling technique in this study uses probability simple random sampling, which is a sample selection technique of providing equal opportunities for members of the population to be selected, the selection or appointment a based on accidental techniques. The data obtained are then analyzed using the Paired T-test analysis to determine the significance of the differences between the variables, which is used as the basis for research in evaluating

\section{Result and Discussion}

Quality of health services at Public Health Centers in Kotamobagu City

Tabel 1. The quality of health services obtained by the community at the Public Health Centers in Kotamobagu City.

\begin{tabular}{|c|c|c|c|c|c|c|c|c|}
\hline \multicolumn{9}{|c|}{ Service Quality } \\
\hline $\begin{array}{c}\text { Service } \\
\text { Dimensions } \\
\text { Variable }\end{array}$ & $\begin{array}{l}\text { Patient } \\
\text { Expected } \\
\text { Service }\end{array}$ & $\begin{array}{l}\text { Provider } \\
\text { Perceive } \\
\text { d service }\end{array}$ & Different & $\begin{array}{c}P- \\
\text { Value } \\
(\alpha< \\
0,05)\end{array}$ & $\begin{array}{c}\text { Patient } \\
\text { Expected } \\
\text { Service }\end{array}$ & $\begin{array}{c}\text { Patient } \\
\text { Expected } \\
\text { Service }\end{array}$ & $\begin{array}{l}\text { Differe } \\
\mathrm{nt}\end{array}$ & $\begin{array}{c}P- \\
\text { Value } \\
(\alpha<0,05)\end{array}$ \\
\hline Tangible & 3,08 & 2,96 & 0,12 & 0,450 & & & & \\
\hline Reliability & 3,09 & 2,09 & 1 & 0,000 & & & & \\
\hline $\begin{array}{c}\text { Responsivenes } \\
s\end{array}$ & 2,99 & 1,87 & 1,12 & 0,000 & 2,95 & 2,63 & 0,32 & 0,000 \\
\hline Assurance & 3,34 & 3,25 & 0,09 & 0.000 & & & & \\
\hline Empathy & 2,24 & 2,98 & $-0,74$ & 0,000 & & & & \\
\hline
\end{tabular}


Based on the data described in table 1. It can be seen that the health services at the Public Health Centers in Kotamobagu City are not optimal, based on the assessment carried out by the community who utilizes health services, it is known that the health services felt by the community are not following what is conveyed. by the health service manager at the Kotamobagu City Health Center with a different value of 0.32 with a significance level of $(\alpha=$ $0.000<0.05)$. The lack of optimal health services at the Kotamobagu City Health Center is evident from the 5 dimensions of service in health services, 4 dimensions are assessed by patients or the community who use health services that are not following what is conveyed by health service providers, namely the Tangible, Reliability, Responsiveness, and Assurance dimensions. The service dimension assessed by the community who utilize health services is appropriate and even exceeds what was conveyed by the health service manager at the Kotamobagu City Health Center, namely the Empathy dimension with a difference value (-0.74) with a significance level of $(\alpha=0.000<0,05)$.

Among the dimensions of health services that are not yet optimal, the Tangible dimension is considered to have an insignificant difference between the health services delivered and those felt by the community who utilize health service facilities at the Kotamobagu City Health Center with a significant value of $(\alpha=0.450>0.05)$. Other dimensions of health services that are not optimal and assessed by the community have a very significant relationship between what was conveyed by health providers at the Public Health Centers in Kotamobagu City, namely the service dimension of Reliability which has a different value of 1 with a significance level of $(\alpha=$ $0.000>0.05)$, the Responsiveness service dimension which has a different value of 1.12 with a significance level of $(\alpha=0.000>0.05)$, and the Assurance dimension which has a different value of 0.09 with a significance level of $(\alpha=0.000>0.05)$.

The value of the difference and the significant value found in the health services felt by the community with that conveyed by the health service provider at the Kotamobagu City Health Center means that the higher the value of the difference and the smaller the significant value found, the lower the perceived quality of health services. by the community in utilizing health services at the Public Health Centers in Kotamobagu City and the lower the value of the difference and the small significant value found, the better the quality of health services felt by the community in the utilization of health services at the Public Health Centers in Kotamobagu City.

High service quality can be created through the fulfillment of Perceived on Tangibles, Reliability, Assurance, Responsiveness and Empathy variables optimally to produce a good picture or impression by patients on health services both in terms of friendliness of officers, professionalism of officers, nursing facilities, availability and completeness supporting tools, timeliness of service, suitability of patient handling procedures and accuracy of officer decision making, (Aliyani , Aritonang, \& Derriawan, 2019).

Several factors support the creation of optimal quality health services through awareness of health workers in providing services, health workers are responsible for all their duties, the 
availability of sufficient operational funds and facilities and infrastructure, the community will give a good assessment of the services provided, (Siswanto, Makmur, \& Lastiti , 2019).

In another study, Sahdam (2018) stated that the quality of health services, in general, cannot be maximized for people who use health services, due to low attention to aspects of reliability, responsiveness, assurance, empathy, and responsibility in health services, both partially and completely. aspects, and will have an impact on health services that are still not optimal, so that community assessments for optimally fast and precise services cannot be given to health providers, to realize this it can be started from service procedures that are not complicated, as well as service delivery. clear and broad information for the public, (Sahdam, 2018).

The quality of health services is less than optimal because the dimensions of Tangible, Reliability, Responsiveness, Assurance, and Empathy are still considered lacking by patients in providing health services, so it is necessary to improve service quality, especially in the dimensions of health service reliability (reliability) and empathy (attention), both This dimension becomes the main measuring point for people who use health services because it creates the first impression on patients. While the tangible dimensions (direct evidence), responsiveness (response), and assurance (guarantee) are considered sufficient but still have to improve the quality of human resources which are the driving force of the organization because they still do not have appropriate educational competencies based on statutory requirements, (Sutriono \& Sudirman, 2020).

According to the results of Purwoastuti's research in 2015 that in health services, employee behavior is something that is able to foster a sense of patient confidence in the provision of services at health service agencies so as to create a sense of comfort for patients. Assurance means that employees master the knowledge and skills needed according to their profession to handle every patient's questions and problems which in turn have an impact on the optimal quality of health services, (Purwoastuti, Endang, \& Walyani, 2016).

On the whole, public health centers are seen as having fairly good services, but some have not been able to carry out optimal services in several elements of public health centers services, including speed of service, the accuracy of implementation of service time schedules, comfort in the service unit environment, increased intensity of coaching and facilities. related to public health centers such as treatment procedures are important things to do so that the performance of officers becomes more patterned, (Listyowati, Indrayathi, \& Sri, 2016).

Health services are less qualified in establishments of health service providers is still less than the maximum, due to several factors: infrastructure medical support dimensions (tangible/ visibility physical) that have not been fulfilled in an integrated manner, then the dimension (reliability/reliability) is scheduled doctor's surgery specialist which is uncertain, then the commitment of Human Resources (HR) in providing health services is still not implemented in keeping the practice schedule, and the number of Human Resources is not ideal because it is not comparable to the room, namely 13 service rooms, (Mursyidah \& Nurfajriyah, 2017).

\section{Conclusion}


The quality of health services received by the community who utilize services in all public health centers in Kotamobagu City is not considered optimal. Dimensions in health services that are considered low or lacking by the community in their implementation at the public health centers are the dimensions of Reliability, Responsiveness, Assurance, and Empathy.

\section{Acknowledgements}

Our thanks to the Institute of Health and Technology Graha Medika, which has facilitated and supported this research, as well as friends of lecturers, researchers, and students in the Faculty of Health, in particular within the scope of the Study Program of Public Health who has supported and helped in the process this research. As well as thanks to all the Public Health Centers in Kotamobagu City who have accommodated this research to completion.

\section{Conflict of Interest}

All Authors declare no conflict of interest and agree with the content of the manuscript.

\section{References}

Aliyani , L. M., Aritonang, \& Derriawan. (2019). Pengaruh Kualitas Pelayanan Dan Perceived Quality Terhadap Kepuasan Pasien BPJS-Kesehatan Rawat Jalan Rsud Bayu Asih Purwakarta. Jurnal Ilmiah Kedokteran Medika Tadulako, 132-139.

Etlidawati, \& Handayani, D. Y. (2017). Hubungan Kualitas Mutu Pelayanan Kesehatan Dengan

Kepuasan Pasien Peserta Jaminan Kesehatan Nasional . MEDISAINS: Jurnal Ilmiah Ilmu-ilmu Kesehatan, 142-147. https://doi.org/10.22216/jen.v2i1.461

Fahmi, A. (2016). Analisis Penyebab Rendahnya Budaya 3S (Senyum, Sapa, Salam) Pada Karyawan Rumah Sakit XYZ. Jurnal Kesehatan Aiptinakes Jatim, 24-35.

Hadi. (2017). Buku Ajar Manajemen Keselamatan Pasien. Yogyakarta: Deepublish.

Herri. (2017). Dasar-dasar Komunikasi Bagi Perawat. Jakarta: Kencana.

Listyowati, R., Indrayathi, P. A., \& Sri, N. M. (2016). Persepsi Pengguna Layanan Kesehatan

Primer Mengenai Kualitas Pelayanan Pada Puskesmas Badan Layanan Umum Di Kabupaten Gianyar. Archive Community Health, 47-55.

Mursyidah, L., \& Nurfajriyah, I. (2017). Kualitas Pelayanan Kesehatan di RSUD Kabupaten Sidoarjo. JKMP (Jurnal Kebijakan dan Manajemen Publik). https://doi.org/10.21070/jkmp.v5i1.1322

Purwoastuti, Endang, \& Walyani, E. S. (2016). Mutu Pelayanan kesehatan dan Kebidanan. Yogyakarta: Pustaka Baru Press.

Sahdam. (2018). Kualitas Pelayanan Kesehatan Rumah Sakit Umum Daerah Mokopido Kabupaten Tolitoli. Jurnal Katalogis, 141-150.

Siswanto, H., Makmur, M., \& Lastiti , N. (2019). Analisis Kualitas Pelayanan Kesehatan Dalam Operasionalisasi Program Mobil Sehat. Jurnal Administrasi Publik (JAP), 1821-1826.

Sudirman, S. (2018). Work Motivation and Achievement of Health Officers in Basic Program Public Health Center in Sojol District. Health Notions, 2(4), 450-452. https://doi.org/10.33846/hn24 
Sutriono, D., \& Sudirman. (2020). Health Services Description (Pharmacy Installation) In District Hospital Prof. Dr. H. Aloei Saboe Gorontalo City. Jurnal IKESMA, 117-125. https://doi.org/10.19184/ikesma.v16i2.19466 